\title{
Hubungan pemeriksaan LED dan CRP pada penegakkan diagnosis Spondilitis Tb di RSUP dr. M. Djamil Padang tahun 2014-2016
}

\author{
Bayu Fajar Wibowo ${ }^{1}$, Menkher Manjas², Roni Eka Sahputra², Erkadius ${ }^{2}$ \\ 1. PPDS Fakultas Kedokteran, Universitas Andalas; 2. Fakultas Kedokteran, Universitas Andalas
}

Korespondensi: Bayu Fajar Wibowo, email: beevazzwee@yahoo.com

\begin{abstract}
Abstrak
Spondilitis Tuberkulosis (Tb) merupakan manifestasi Tb tulang yang paling berbahaya dan paling sering ditemukan. Perubahan nilai hematologi berupa pengukuran nilai Laju Endap Darah (LED) dan C-Reactive Protein (CRP) digunakan dalam penegakkan diagnosa, penilaian prognosis dan efektivitas pengobatan Spondilitis Tb. Tujuan: Untuk mengetahui hubungan dan akurasi diagnostik LED dan CRP pada pasien spondilitis Tb. Metode: Penelitian ini menggunakan desain retrospective cohort study pada 53 penderita diduga Spondilitis Tb yang belum pernah mendapatkan terapi OAT, tetapi telah menjalani operasi dan pemeriksaan histopatologi pada periode Januari 2014 hingga Desember 2016, di RSUP dr. M. Djamil Padang dan diolah dengan analisis Fisher's Exact Test. Hasil: Tidak terdapat hubungan yang bermakna antara kejadian Spondilitis Tb dan nilai LED dengan $p$-value 0,280 $(p>0,05)$. Tidak terdapat hubungan yang bermakna antara kejadian Spondilitis Tb dengan nilai kualitatif CRP dengan $p$-value 0,886 ( $p>0,05)$. Simpulan: Berdasarkan hasil tersebut, dapat disimpulkan bahwa pemeriksaan LED dan CRP tidak spesifik untuk diagnosis Spondilitis Tb, kecuali CRP memiliki sensitivitas yang tinggi.
\end{abstract}

Kata kunci: Sponditilis Tb; LED; CRP; diagnostik

\begin{abstract}
$T b$ Spondylitis is the most dangerous and most common manifestation of skeletal Tb. Changes in hematologic values of measurements of the Blood Endo Rate (LED) and C-Reactive Protein (CRP) were used in diagnosis, assessment of prognosis and effectiveness of Tb spondylitis treatment. Objectives: Determining the relationship and accuracy of diagnostic LED and CRP in patients with Tb spondylitis. Methods: This study used a retrospective cohort study design in 53 suspected $T b$ Spondylitis patients who had never received OAT therapy, but had undergone surgery and histopathologic examination in the period January 2014 to December 2016, at dr. M. Djamil Central General Hospital Padang and processed by Fisher's Exact Test. Results: There was no significant relationship between Tb Spondylitis incidence and LED value with $P$ value 0.280 ( $p>0.05$ ). There was no significant relationship between $T b$ Spondylitis incidence and CRP qualitative value with $P$ value 0.886 ( $p>0.05$ ). Conclusions: Based on these results, it can be concluded that LED and CRP examinations are not specific for the diagnosis of Tb spondylitis, unless CRP has high sensitivity. Keywords: Tuberculous Spondylitis; ESR; CRP; diagnostic
\end{abstract}




\section{PENDAHULUAN}

Spondilitis Tuberkulosis (Tb) atau dikenal juga dengan Pott's Disease, mengenai sekitar 1-5\% dari seluruh kasus Tb. Spondilitis Tb merupakan manifestasi Tb tulang yang paling berbahaya dan yang paling sering ditemukan, yaitu sekitar 40$50 \%$ dari seluruh kasus Tb tulang. ${ }^{1-6}$

Gejala yang ditimbulkan tidak hanya mengenai tulang dan jaringan lunak di sekitarnya, tapi juga mengenai spinal cord. Kelainan neurologis dilaporkan terjadi pada $10-47 \%$ kasus spondilitis $\mathrm{Tb}$, dengan deformitas kifosis paling sering ditemui. Di negara yang sedang berkembang penyakit ini merupakan penyebab paling sering untuk kondisi paraplegia non-traumatik. ${ }^{4-7}$

Penegakkan diagnosis yang tepat serta terapi yang adekuat dapat menghasilkan prognosis yang baik. Saat ini spondilitis Tb meningkat jumlahnya akibat adanya peningkatan kasus pada pasien-pasien dengan sindrom defisiensi imun, peningkatan penyalahgunaan penggunaan obat intravena, peningkatan pada pembedahan dan instrumentasi pada prosedur operasi tulang belakang, terutama pada negara berkembang. Gejala klinis pada spondilitis Tb (Triad of Pott) yaitu gibbus, abses spinal, dan paraparesis. ${ }^{1-9}$

Insiden Spondilitis Tb bervariasi di seluruh dunia dan biasanya berhubungan dengan kualitas pelayanan kesehatan masyarakat yang tersedia dan kondisi sosial di negara tersebut. Berdasarkan data WHO tahun 2010, Indonesia adalah kontributor penderita tuberkulosis nomor 3 di dunia setelah India dan Cina. Tingkat virulensi Mycobacterium tuberculosis dari tahun ke tahun terus meningkat dan diperkirakan prevalensi Multidrug Resistant Tb (MDRTb) sebanyak 650.000 kasus dengan kematian karena MDR-Tb sebanyak 150.000 kasus. ${ }^{10-14}$

Bermacam-macam haematological markers telah digunakan untuk membantu dalam penegakkan diagnosa spondilitis Tb. Pemeriksaan ini juga telah digunakan di dalam menilai prognosis efektivitas pengobatan yang diberikan. Perubahan nilai hematologi pada peningkatan nilai leukosit, anemia, peningkatan nilai LED dan CRP ditemukan pada tuberkulosis aktif. Pemeriksaan LED dan CRP merupakan dua pemeriksaan laboratorium yang paling sering diukur dalam menilai respon suatu proses inflamasi sistemik. Namun masih terdapat perbedaan pendapat mengenai akurasi dan sensitivitas pemeriksaan LED dan CRP di dalam memonitor pasien-pasien positif Tb. ${ }^{15-18}$

LED merupakan tes non spesifik yang nilainya berkaitan dengan perubahan nilai protein plasma. Pada infeksi, inflamasi, degeneratif dan keganasan, nilainya akan meningkat, seperti halnya peningkatan nilai fibrinogen, imunoglobulin dan CRP. Nilai LED juga dipengaruhi oleh berbagai macam faktor, seperti anemia, kehamilan, hemoglobinopati, hemokonsentrasi, dan penggunaan obat anti inflamasi. Nilai LED dapat meningkat pada penderita Tb hingga lebih dari $100 \mathrm{~mm} / \mathrm{jam}$, seiring 
meningkatnya viskositas darah akibat peningkatan kadar imunoglobulin, seperti IgG dan IgA. Penurunan nilai LED merupakan indikator yang baik dalam menilai kontrol pada perkembangan suatu penyakit. ${ }^{19-21}$

CRP dikenal sebagai protein fase akut yang mencerminkan pengukuran respon fase akut. Fase akut mewakili kejadiankejadian lokal dan sistemik pada inflamasi. Respon lokal meliputi vasodilatasi, agregasi platelet, kemotaksis neutrofil dan pelepasan enzim lisosomal. Respon sistemik meliputi demam, leukositosis dan perubahan sintesis hepatik pada proteinprotein fase akut (protein hepatik, yaitu peningkatan dan penurunan pada konsentrasi serum minimal 25\%). Karena respon fase akut relatif tidak spesifik, maka nilai pada pengukuran konsentrasi protein fase akut dapat mencerminkan aktivitas inflamasi pada penyakit. Seperti halnya pada tumor markers, protein fase akut dapat memonitor respon penyakit pada intervensi pengobatan. ${ }^{21,22}$

Nilai normal CRP pada level plasma pada orang sehat berkisar antara $1 \mathrm{mg} / \mathrm{L}-<10$ $\mathrm{mg} / \mathrm{L}$. Nilai akan meningkat dalam 4-6 jam setelah awal dari cedera jaringan hingga menjadi beberapa kali lipat dalam 24-48 jam. CRP akan tetap tinggi pada respon fase akut dan kembali normal pada penyembuhan struktur dan fungsi jaringan. Pengukuran CRP secara serial dapat digunakan sebagai alat diagnostik pada infeksi, monitoring efikasi pengobatan atau pada deteksi dini kejadian relap. Penanganan awal dimulai dengan obat anti $\mathrm{Tb}$ dan tindakan pembedahan dilakukan jika defisit neurologis ditemukan dan bersifat progresif. Indikasi operasi adalah nyeri yang sangat kuat akibat abses yang meluas, gangguan neurologis akibat kompresi pada spinal cord, sekuester tulang dan disc, deformitas kifosis progresif dan instabilitas. ${ }^{5,7,21}$

Penelitian ini dilakukan dengan tujuan mengetahui hubungan antara hasil pemeriksaan LED dan CRP dengan penegakan diagnosis Spondilitis Tb.

\section{METODE}

Penelitian ini menggunakan desain retrospective cohort study yang dilakukan pada bulan Maret - September 2017, dan dilakukan di Instalasi Rekam Medik RSUP dr. M. Djamil Padang dengan populasi semua penderita Spondilitis $\mathrm{Tb}$ yang memenuhi kriteria inklusi yang berobat ke RSUP dr. M. Djamil Padang selama periode Januari 2014 - Desember 2016.

Kriteria Inklusi Penderita Spondilitis Tb berdasar anamnesis dan pemeriksaan fisik yang belum pernah mendapatkan terapi OAT sebelumnya dan menjalani operasi dan pemeriksaan histopatologis. Data diolah dengan menggunakan analisis Fisher's Exact Test untuk melihat hubungan antara kejadian Spondilitis $\mathrm{Tb}$ dengan nilai LED dan CRP. Faktor kemaknaan hubungan ditentukan dengan odds ratio dan dengan confidence interval $95 \%$. Nilai $p<0,05$ dinyatakan sebagai batas kemaknaan. 


\section{HASIL DAN PEMBAHASAN}

Dari data yang diambil dari bagian rekam medis di RSUP Dr. M. Djamil Padang, didapatkan 53 pasien yang diduga Spondilitis Tb. Dari temuan tersebut sebanyak 4 kasus temuan pemeriksaan histopatologinya bukan disebabkan oleh radang kronik $\mathrm{Tb}$. Temuan histopatologi dapat mengkonfirmasi diagnosa Spondilitis Tb pada sekitar $60 \%$ kasus. Temuan sitologi yang paling sering terlihat yaitu adanya epitheloid cell granuloma (90\%), granular cell necrotic (83\%) dan infiltrasi sel limfosit (76\%). Scattered multinucleated dan sel
Datia Langhan's dapat terlihat pada 56\% kasus. Hasil biopsi false-negative lazim terjadi, bisa disebabkan karena lokasi pengambilan sampel yang tidak tepat, pengambilan potongan jaringan yang tidak tepat pada pembuatan spesimen, atau karena adanya infeksi sekunder yang dominan sehingga menyebabkan pengaburan kesimpulan hasil pemeriksaan. Oleh karena itu, diagnosis Spondilitis $\mathrm{Tb}$ harus ditegakkan dengan mempertimbangkan aspek temuan klinis, laboratorium serta radiologi jika hasil temuan kuman $\mathrm{Tb}$ negatif. ${ }^{22,23}$

Tabel 1. Latar belakang dan pemeriksaan fisik terhadap pasien dengan Spondilitis

\begin{tabular}{lrrrrrrrr}
\hline Spondilitis & \multicolumn{2}{c}{ Jenis Kelamin } & \multicolumn{2}{c}{ Keluhan Utama } & \multicolumn{2}{c}{$\begin{array}{c}\text { Frankel } \\
\text { Type }\end{array}$} & \multicolumn{2}{c}{ Lokasi } \\
& Laki-laki & Perempuan & \multicolumn{2}{c}{$\begin{array}{c}\text { Nyeri } \\
\text { pinggang }\end{array}$} & $\begin{array}{c}\text { Kelemahan } \\
\text { tungkai }\end{array}$ & $\begin{array}{c}\text { BC } \\
\text { tun }\end{array}$ & Torakal & Lumbal \\
\hline Tb & 26 & 23 & 39 & 10 & 4 & 45 & 30 & 19 \\
Non-Tb & 0 & 4 & 2 & 2 & 0 & 4 & 2 & 2 \\
Total & 26 & 27 & 41 & 12 & 4 & 49 & 32 & 21 \\
\hline
\end{tabular}

Latar Belakang Pasien dan Hubungannya dengan Kejadian Spondilitis Tb

Latar pasien, yaitu usia, jenis kelamin dan keluhan utama yang diderita pasien, berkenaan dengan hubungannya dengan kejadian Spondilitis Tb, kejadian Spondilitis Tb pada usia < 40 tahun (29 orang) lebih banyak ditemukan dibanding kisaran usia $\geq 40$ tahun (20 orang). Sedangkan pada Spondilitis Non Tb lebih banyak ditemukan penderita berusia $\geq 40$ tahun ( 3 orang) dibanding usia $<40$ tahun (1 orang). Namun, secara statistik dengan $p$-value $0,181(p>0,05)$ tidak ada hubungan yang bermakna antara kejadian Spondilitis Tb dengan usia penderita.

Adanya riwayat kontak dengan penderita Tb dan lamanya paparan, meningkatkan risiko transmisi dari kuman Tb. Perkembangan kuman Tb dipengaruhi oleh status imunitas seseorang. Pada penderita dengan imunitas yang baik, $90 \%$ penyakit Tb tidak akan berkembang. Sebaliknya pada penderita dengan imunitas yang menurun, atau anak-anak usia $<5$ tahun atau pada usia lanjut, penyakit ini akan berkembang. ${ }^{24}$ Secara analisa statistik, tidak ada hubungan yang bermakna antara 
kejadian Spondilitis Tb dengan usia penderita.

Kejadian Spondilitis Tb pada laki-laki (26 orang) lebih banyak ditemukan dibanding perempuan (23 orang). Sedangkan pada Spondilitis Non-Tb hanya ditemukan pada perempuan, yaitu 4 orang. Secara statistik dengan $p$-value 0,060 ( $p>0,05)$ tidak ada hubungan yang bermakna antara kejadian Spondilitis Tb dengan jenis kelamin.

Beberapa literatur menyebutkan bahwa pria lebih sering terkena dibanding wanita. Namun insiden Spondilitis Tb tidak ditentukan oleh jenis kelamin, melainkan berhubungan dengan kualitas pelayanan kesehatan masyarakat yang tersedia dan kondisi sosial di masing-masing negara. Tb berkembang antara lain dipengaruhi oleh status imunitas seseorang, adanya riwayat penyakit kronik (Diabetes melitus), penyalahgunaan alkohol dan obat-obatan terlarang, faktor sosial serta status gizi. $^{3,10,22,25,26}$

Kejadian Spondilitis Tb dengan keluhan utama nyeri pinggang/punggung (39 orang) lebih banyak ditemukan dibanding keluhan utama karena kelemahan tungkai/benjolan (10 orang). Sedangkan pada Spondilitis Non-Tb keluhan utama nyeri pinggang/punggung ( 2 orang) sama dengan keluhan utama karena kelemahan tungkai/benjolan ( 2 orang). Namun, secara statistik dengan $p$-value $0,185 \quad(p>0,05)$ tidak ada hubungan yang bermakna antara kejadian Spondilitis Tb dengan keluhan utama.
Nyeri punggung merupakan keluhan yang paling sering dirasakan penderita Spondilitis Tb. Intensitas nyeri sendiri bervariasi, mulai dari nyeri tumpul yang konstan hingga nyeri hebat. Nyeri biasanya sesuai dengan lokasi lesi dan paling sering di vertebra thorakal. Nyeri dapat ditimbulkan oleh karena adanya pergerakan dari tulang belakang, batuk dan weight bearing. Hal ini disebabkan oleh karena adanya advanced disk disruption dan instabilitas dari tulang belakang, kompresi pada nerve root, atau karena adanya fraktur patologis. Namun, secara analisa statistik pada penelitian ini tidak ditemukan adanya hubungan yang bermakna antara kejadian Spondilitis Tb dengan keluhan utama. ${ }^{1,22}$

Hasil Pemeriksaan Fisik dan Penunjang serta Hubungan dengan Kejadian Spondilitis $T b$

Hasil pemeriksaan pada pasien dengan Spondilitis Tb, meliputi pemeriksaan fisik dengan menggunakan Frankel Classification Grading System. ${ }^{27}$ Pemeriksaan radiologi (lokasi lesi) serta hubungannya dengan kejadian Spondilitis Tb dengan temuan klinis Frankel Type $D$ dan Type E (45, masing-masing 43 dan 2 orang) lebih banyak dibandingkan dengan temuan klinis Frankel Type B dan Type C (4, masing-masing 2 orang). Sedangkan pada Spondilitis Non-Tb temuan klinis hanya ditemukan pada Frankel Type $D$ yaitu 4 orang. Namun, secara statistik dengan $p$ value $0,724(p>0,05)$ tidak ada hubungan 
yang bermakna antara kejadian Spondilitis Tb dengan Frankel Type.

Dari pemeriksaan neurologis yang dilakukan, berdasarkan Frankel Classification Grading System, didapatkan bahwa temuan Frankel Type $D$ dan Type $E$ lebih banyak dijumpai pada penderita Spondilitis Tb (45 orang). Hal ini mungkin disebabkan karena sebagian besar penderita Spondilitis Tb datang berobat dengan keluhan utama nyeri yang dirasakan di punggung dan pinggang, sehingga progresivitas yang lebih lanjut akan defisit neurologis yang ditimbulkan dapat segera dicegah. ${ }^{20}$

Kejadian Spondilitis Tb dengan lokasi lesi, berdasarkan temuan radiologi, lokasi lesi di thorakal (30 orang) lebih banyak dibandingkan dengan lesi di lumbal (19 orang). Sedangkan pada Spondilitis Non-Tb temuan lesi di thorakal (2 orang) sama dengan di lumbal (2 orang). Namun, secara statistik dengan $p$-value $0,356 \quad(p>0,05)$ tidak ada hubungan yang bermakna antara kejadian Spondilitis Tb dengan lokasi lesi.

Hal ini sesuai dengan beberapa literatur yang mengatakan bahwa vertebra thorakal adalah lokasi tersering pada Spondilitis Tb, diikuti oleh vertebra lumbalis dan jarang pada vertebra cervikalis. ${ }^{19,24}$ Spondilitis Tb dapat terjadi oleh karena adanya penyebaran kuman dari lesi primer, baik secara hematogen (arteri maupun vena) atau melalui penyebaran langsung dari fokus infeksi melalui sistem limfatik. Tingginya kejadian di level thorakal pada vertebra bisa disebabkan oleh karena distribusi infeksi dari kombinasi antara hematogen, sistem limfatik dan invasi langsung. Ini ditemui pada infeksi Tb pulmonal, dimana seringnya terjadi keterlibatan mediastinal lymph nodes dan pleura. $^{28}$

Hasil Pemeriksaan LED serta Hubungan dengan Kejadian Spondilitis Tb

Hasil pemeriksaan nilai LED pada pasien dengan Spondilitis Tb, serta hubungan kemaknaannya didapatkan Odds ratio sebesar 0,347 dengan sensitivitas 51,0\% dan spesifisitas $75,0 \%$. Nilai positive predictive value (PPV) didapatkan 89,3\% dan negative predictive value (NPV) 96,0\%. Kejadian Spondilitis Tb dengan nilai LED menunjukkan bahwa nilai LED $\geq 80$ (25 orang) lebih banyak dibanding dengan nilai LED <80 (24 orang). Sedangkan pada Spondilitis Non-Tb nilai LED $\geq 80$ (3 orang) lebih banyak dibanding dengan nilai LED $<80$ (1 orang). Namun, secara statistik dengan $p$-value $0,280(p>0,05)$ tidak ada hubungan yang bermakna antara kejadian Spondilitis Tb dengan nilai LED.

Laju endap darah merupakan tes non spesifik yang nilainya berkaitan dengan perubahan nilai protein plasma. Nilai LED dapat meningkat pada penderita Tb hingga lebih dari $100 \mathrm{~mm} / \mathrm{jam}$, seiring meningkatnya viskositas darah akibat peningkatan kadar imunoglobulin, seperti IgG dan IgA. Peningkatan nilai LED pada pasien-pasien $\mathrm{Tb}$ dibanding individu normal dan pemeriksaan LED berguna di 
dalam menunjukkan perkembangan penyakit dan keberhasilan dalam pengobatan Tb. ${ }^{19-21}$

Tabel 2. Nilai LED pada Spondilitis

\begin{tabular}{lrr}
\hline Spondilitis & LED $(\geq 80)$ & LED $(<80)$ \\
\hline Tb & 25 & 24 \\
Non-Tb & 3 & 1 \\
Total & 28 & 25 \\
\hline
\end{tabular}

Hasil Pemeriksaan CRP Serta Hubungan dengan Kejadian Spondilitis Tb

Hasil pemeriksaan nilai kualitatif CRP pada pasien dengan Spondilitis Tb didapatkan Odds ratio sebesar 0,295 dengan sensitivitas $91,8 \%$ dan spesifisitas $75,0 \%$. Nilai positive predictive value (PPV) didapatkan $93,8 \%$ dan negative predictive value (NPV) 80,0\%. Kejadian Spondilitis Tb dengan nilai CRP (+) (45 orang) lebih banyak dibanding dengan nilai CRP (-) (4 orang). Sedangkan pada Spondilitis Non-Tb nilai CRP (+) (3 orang) lebih banyak dibanding dengan nilai CRP (-) (1 orang).

Tabel 3. Nilai kualitatif CRP pada Spondilitis

\begin{tabular}{lrr}
\hline Spondilitis & CRP $(+)$ & CRP $(-)$ \\
\hline Tb & 45 & 3 \\
Non-Tb & 3 & 1 \\
Total & 49 & 4 \\
\hline
\end{tabular}

Pemeriksaan serum CRP saat ini telah dikembangkan oleh beberapa peneliti sebagai salah satu indikator dalam membedakan antara infeksi kuman spesifik Tb dengan infeksi kuman Non-Tb. Dari beberapa penelitian yang telah dilakukan, sebagian menunjukkan adanya kemaknaan dalam peningkatan serum CRP dengan perbedaan antara infeksi kuman Tb dengan infeksi Non-Tb dan beberapa penelitian mengatakan tidak ada kemaknaan di dalamnya. ${ }^{29-31}$ Pada penelitian ini, secara analisa statistik, tidak ditemukan adanya hubungan yang bermakna antara kejadian Spondilitis Tb dengan nilai kualitatif CRP.

\section{SIMPULAN}

Berdasarkan hasil penelitian dan pembahasan dapat disimpulkan bahwa:

Tidak ada hubungan yang bermakna antara kejadian Spondilitis Tb dengan nilai LED, sensitivitas $51,0 \%$, spesifisitas $75,0 \%$.

Tidak ada hubungan yang bermakna antara kejadian Spondilitis $\mathrm{Tb}$ dengan nilai kualitatif CRP, sensitivitas 91,8\%, spesifisitas $75,0 \%$.

\section{DAFTAR PUSTAKA}

1. Qadeer M, Sharif S. Spinal Tb Infections. World Spinal Column J. 2015; 1:8-14.

2. Surjono E. Diagnosis dan Tatalaksana Spondilitis Tb Pada Anak. Damianus Journal Of Medicine. 2011; 10(3).

3. De Backer AI, Mortele KJ, Vanschoubroeck IJ, Deeren D, Vanhoenacker FM, De Keulenaer BL, et al. Tuberculosis Of The Spine: CT And MR Imaging Features. JBR-BTR. 2005; 88(2):92-7. 
4. Rasouli MR, Mirkoohi M, Vaccaro AR, Yarandi KK, Rahimi-Movaghar V. Spinal Tuberculosis: Diagnosis And Management. Asian Spine Journal. 2012; 6:294-308.

5. Ramirez E, Ochoa M, Ordonez F. Surgical Treatment of Spinal Tuberculosis By Anterior Approach. Coluna/Columna. 2013; 12(4).

6. Altıntaş N, Türkeli S, Yılmaz Y, Sarıaydın M, Yaşayancan N. A Rare Case of Tuberculosis Psoas Abscess. European Journal Of General Medicine. 2012; 9:159-161.

7. Ito $M$, Sudo H, Abumi K, Kotani $Y$, Takahata $M$, Fujita $M$, et al. Minimally Invasive Surgical Treatment for Tuberculosis Spondylodiscitis. Minim Invasive Neurosurg. 2009; 52(5-

6):250-3.

8. Kadhiravan T, Deepanjali S. Role Of Corticosteroids In The Treatment Of Tuberculosis: An Evidence-Based Update. Indian J Chest Dis Allied Sci. 2010; 52(3):153-8.

9. Jeong S-J, Choi S-W, Youm J-Y, Kim H-W, Ha H-G, Yi J-S. Microbiology and Epidemiology of Infectious Spinal Disease. J Korean Neurosurg Soc. 2014; 56(1): 21-27.

10. Vitriana. Spondilitis Tuberkulosa. Bandung: Universitas Padjadjaran; 2002. Tersedia dari URL: http://repository.unpad.ac.id/1614/1/spondilitis tuberkulosa.pdf. Diakses 13 Maret 2017.

11. Kusuma YA, Prijambodo B. Validity of Polymerase Chain Reaction (PCR) Method in Diagnosing Spondylitis Tuberculosis. Journal Orthopaedi and Traumatology Surabaya. 2012; 13(3):98-103.

12. Gülbay BE, Gürkan OU, Yildiz OA, Onen ZP, Erkekol FO, Baççioğlu A, et al. Side Efffects Due To Primary Antituberculosis Drugs During The Initial Phase Of Theraphy In 1149 Hospitalized Patients For Tuberculosis. Respir Med. 2006; 100(10):1834-42.

13. Saltini C. Chemotheraphy and Diagnosis of Tuberculosis. Respir Med. 2006; 100(2):208597.

14. Evans DJ. The Use Of Adjunctive Corticosteroids In The Treatment Of Pericardial, Pleural And Meningeal Tuberculosis: Do They Improve Outcome. Respir Med. 2008; 102(6):793800.

15. Daniel K, Dunn R. Comparison of Platelet Count In Tuberculosis Spine to Other Spine Pathology. Europe Spine Journal. 2013; 22:2810-2814.

16. Jeremiah ZA, Leonard I. Discordantly Elevated Erythrocyte Sedimentation Rate (ESR) And Depressed C- Reactive Protein (CRP) Values In Early Diagnosis Of Pulmonary Tuberculosis Patients In Maiduguri Nigeria. Open Journal Of Blood Disease. 2013; 3:74-77.

17. Martins C, Gama AC, Valcarenghi D, Batschauer AP. Markers Of Acute Phase Response In The Treatment Of Pulmonary Tuberculosis. J Bras Patol Med Lab. 2014; 50:428-433.

18. Bashir AB, Ageep Ak, Abufatima A, Mohamedani AA. Reactive Thrombocytosis And Erythrocyte Sedimentation Rate In Patients With Pulmonary Tuberculosis. Journal of Medical Laboratory and Diagnosis. 2014; 5:29-34. 
19. Mahalakshamamma V, Raju EA, Jhansi K. Erythrocyte Sedimentation Rate Values In Pulmonary Tuberculosis Versus Normal Healthy Peoples In Khammam Region Of Telangana, India. International Journal Of Integrative Medical Sciences. 2016; 3:207-10.

20. Rao VS, Murthy KS. High Sensitive C-reactive Protein? Is It Significant In Tuberculous Spondylitis. International Journal Of Scientific Study. 2016; 3:274-278.

21. Husain TM, Kim DH. C-Reactive Protein and Erythrocyte Sedimentation Rate in Orthopaedics. The University of Pennsylvania Orthopaedic Journal. 2002; 15:13-16.

22. Garg RK, Somvanshi DS. Spinal Tuberculosis: A Review. The Journal Of Spinal Cord Medicine. 2011; 34:440-454.

23. Karimi S, Shamaei M, Pourabdollah M, Sadr M, Karbasi M, Kiani A, et al. Histopathological Findings in Immunohistological Staining of the Granulomatous Tissue Reaction Associated with Tuberculosis. Tuberculosis Research and Treatment. 2014; 14:1-4.

24. National Tuberculosis Management Guidelines. Department Health Republic of South Africa. 2014. Tersedia dari:

http://familymedicine.ukzn.ac.za/Libraries/Guidlines Protocols/Tb Guidlines 2009.sflb. ashx. Diakses 18 Agustus 2017.

25. Jupiter JB. Orthopedic Priciples - A Resident's Guide. New York: Springer; 2005. P550565.

26. Hodler J, Schulthess GK, Zoliikofer CH. Musculoskeletal Diseases: Diagnostic Imaging And Interventional Techniques. Springer, NewYork. 2005; 128-131.

27. American Spinal Injury Association. International Standards for Neurological Classification Of SCl. Tersedia dari URL: http://asia-spinalinjury.org./wpcontent/uploads/2016/02/International Stds Diagram Worksheet.pdf. Diakses 20 Februari 2017.

28. Ibrahim EK, Ahmed EG, Elbadawi NE, Mohammed MM. Vertebral Distribution of Pott's Disease of the Spine Among Adult Sudanese Patients in Khartoum Sudan. American Journal of Health Research. 2014; 2(3):93-96.

29. Shameem M, Fatima N, Ahmad A, Malik A, Husain Q. Correlation of Serum C-Reactive Protein With Disease Severity In Tuberculosis Patients. Open Journal of Respiratory Diseases. 2012; 2:95-100.

30. Wilson D, Badri M, Maartens G. Performance of Serum C-Reactive Protein as a Screening Test For Smear-Negative Tuberculosis in an Ambulatory High HIV Prevalence Population. Plos ONE. 2011; 6:1528.

31. Khuder HS, Norrei AY, Khuder YS. High Sensitive C-Reactive Protein in Patients With Pulmonary Tuberculosis in Tikrit City. International Journal of Advances in Pharmacy, Biology and Chemistry. 2013; 2(4):611-15. 